\title{
"O eterno fascismo italiano" e a resistência dos romances de Ignazio Silone, Carlo Levi e Vasco Pratolini
}

\author{
Gabriela Kvacek Betella*
}

\section{RESUMO}

Silone, Levi e Pratolini são escritores especialmente citados pela postura antifascista na atividade política e na atitude literária. Três de suas principais narrativas representam experiências de contato com as desigualdades agravadas durante o regime, além de retratarem aspectos nefastos no comportamento autoritário dos representantes do Estado fascista. Publicados antes e depois da Segunda Guerra, com enredos cobrindo períodos que vão dos anos de 1920 aos de 1930, Fontamara (1933), Cristo si è fermato a Eboli (1945) e Cronache di poveri amanti (1947) compóem quadros camponeses e urbanos comprometidos com a população esquecida do sul do país e com as pessoas amedrontadas em plena irrupção do terror. Há uma tarefa intelectual de revirar o passado para explicar o presente, estabelecer uma posição, defender a verdade e oferecer uma soluçáo estética para a expressão dela. Os filmes baseados nos romances, aos quais dedicamos uma breve digressão, deram continuidade à proposta $\mathrm{e}$ conseguiram problematizar as visóes sobre os anos que se seguiram ao fascismo.

Palavras-chave: antifascismo; memória; Ignazio Silone; Carlo Levi; Vasco Pratolini.

\section{ABSTRACT}

Silone, Levi and Pratolini are names especially cited for their antifascist stance in political activity and literary attitude. Three of their main narratives represent experience of contact with the inequality worsened during the regime, besides portraying nefarious aspects of the authoritarian behaviour of the Fascist State representatives. Published before and after the World War II, with plots covering a period that spans the 1920's to the 1930's, Fontamara (1933), Cristo si è fermato a Eboli (1945), and Cronache di poveri amanti (1947) compose rural and urban pictures committed to the forgotten population of the Southern region of the country, and to the people scared amid the full irruption of terror. There is an intellectual task of revolving the past to explain the present, of establishing a position, of defending the truth, and offering an aesthetical solution for its expression. The films based on the novels,

DOI - http://dx.doi.org/10.1590/2237-101X0173203

Artigo recebido em 8 de março de 2015 e aprovado para publicação em 28 de outubro de 2015.

* Doutora em Teoria Literária e Literatura Comparada pela Universidade de São Paulo (USP) e professora na Universidade Estadual Paulista Júlio de Mesquita Filho (Unesp), campus de Assis (SP), Brasil. E-mail: gabrielakvacek@uol.com.br. 
to which we dedicate a brief discussion, gave continuity to the proposal, and succeeded in putting in doubt the visions about the years that followed Fascism.

Keywords: Antifascism; memoir; Ignazio Silone; Carlo Levi; Vasco Pratolini.

1.

A ascensão do fascismo na Itália deu-se sob condições nada revolucionárias. A chegada de Mussolini ao poder foi o resultado de açóes constitucionais, assim como também estiveram dentro da legalidade os acontecimentos sucessivos que transformaram um governo tecnicamente constitucional numa ditadura totalitária que perseguiu, destituiu e eliminou os adversários, graças a uma combinação de brutalidade e procedimentos legais. ${ }^{1}$ Além disso, uma inédita combinação de terror, ideologia e propaganda nos autoriza a situar o regime fascista italiano no âmbito do debate sobre a categoria de totalitarismo. Emilio Gentile posiciona-se de modo incisivo com relação aos elementos de propaganda e de "política como espetáculo" ou de "estetização da política”, colocando em segundo plano o caráter de irracionalismo do movimento fascista. Gentile sustenta que o poder fascista era extremamente organizado: "A irracionalidade da cultura fascista, os seus mitos, foram politicamente eficazes porque se conjugaram com a racionalidade da organização e da instituição." ${ }^{2}$

Nos anos de 1930 o regime fascista alcançava pela primeira vez o auge dos seus propósitos, finalizando a construção do estado totalitário, trunfo continuado até a década seguinte, cumprindo os propósitos definidos pelo "caráter dinâmico do totalitarismo como processo contínuo". ${ }^{3}$ A mobilização das massas e a ideologia sacralizada na forma de uma nova religião secular juntaram-se aos fatores de propaganda e à organização como partido para a construção do estado totalitário, com projeto de "modernidade totalitária", se levamos em conta os incentivos tecnológicos, a doutrinação coletiva, o impulso à modernização subordinada aos objetivos de expansão em dimensão continental ou mesmo planetária, fenômeno experimentado pela primeira vez entre os países da Europa Ocidental na Itália fascista. ${ }^{4}$

\footnotetext{
${ }^{1}$ SASSOON, Donald. Mussolini e a ascensão do fascismo. Trad. Clóvis Marques. Rio de Janeiro: Agir, 2009, p. 20.

2 "L'irrazionalità della cultura fascista, i suoi miti, furono politicamente efficaci perché si coniugarono con la razionalità dell'organizzazione e dell'istituzione". GENTILE, Emilio. Fascismo. Storia e interpretazione. Roma-Bari: Laterza, 2002, p. 61, tradução nossa. Para uma recensão das polêmicas e dos protagonistas que se entrecruzam na questão do caráter totalitário do fascismo, indicamos GENTILE, Emilio. Fascismo e totalitarismo. La polemica e la ricerca. In: GENTILE, Emilio. La via italiana al totalitarismo, 3. ed. Roma: Carocci, 2008, pp. 299-313.

3 "Carattere dinamico del totalitarismo come processo continuo". GENTILE, Emilio. Fascismo. Storia e interpretazione, op. cit., p. 70, tradução nossa.

${ }^{4}$ GENTILE, Emilio. Introduzione. In: GENTILE, Emilio (Org.). Modernità totalitaria. Il fascismo italiano. Roma-Bari: Laterza, 2008, p. 9.
} 
As representaçôes que estudamos se complementam para ressaltar momentos do regime que chegara ao poder como uma espécie de segundo Risorgimento, como uma revolução política e social, recebido com simpatia mesmo por uma respeitada intelectualidade. Nos primeiros anos, não só o verdadeiro caráter totalitário sob pretensóes revolucionárias é revelado, como a face cruel e arbitrária do regime aparece. De um modo geral, a cultura italiana viveu tempos difíceis, sobretudo após 1925, com a limitação das liberdades de expressão e as consequências de restriçóes como as prisôes e o exílio de pessoas ligadas à vida cultural e política, a censura de revistas e livros, o prejuízo da narrativa, que sobrevive nesses anos retomando elementos do naturalismo para deformar a realidade e esconder problemas, assim como retorna ao romance histórico e incorpora até o realismo mágico.

$\mathrm{Na}$ prática, o período fascista pode ser encarado como desastrosa consequência de um processo que não conseguiu deter certas ambiçóes oportunas. Os efeitos devastadores da Primeira Guerra puderam ser vistos nas reviravoltas econômicas, políticas e morais por toda a Europa. Além das dificuldades na passagem de uma situação de guerra para uma situação de paz, as agitaçôes sociais (do proletariado, da pequena burguesia) e as transformaçôes de ideias, a Itália particularmente viveu um pós-guerra desastroso devido à fragilidade do governo de Francesco Nitti, no período entre 1919 e 1920.

Assim que a Itália declara guerra com a França, em 1940, esse governo começa a caminhar para a ruína, em primeiro lugar pela opinião pública bastante sensibilizada com o rompimento do regime com o povo italiano. Em seguida, as derrotas em campos de batalha e o recrudescimento da repressão fascista permitiram o surgimento e a difusão de uma luta antifascista, cujas origens na clandestinidade e no exílio dos partidos banidos desde os anos de 1920 alimentou, desde o período entreguerras, o fortalecimento da natureza combativa de alguns setores, como se pode verificar por meio da história do Partido Comunista Italiano, cuja fundação em 1921, guiada por Antonio Gramsci e Amadeo Bordiga, marca o início de uma atuaçáo contra o fascismo republicano. Durante a guerra, o PCI assume o papel de organização da Resistência, antifascista por natureza e contrária à ocupação alemã nazista. Além de tudo, os bombardeios que se intensificaram sobre o país, mais o desembarque de tropas inglesas e norte-americanas em julho de 1943 na Sicília (acompanhado de uma série de horrores incomparáveis) traçaram a destituição do líder Benito Mussolini.

É preciso lembrar que os últimos anos da guerra não pareciam acenar para a paz no território italiano. Na síntese de Mariarosaria Fabris, ${ }^{5}$ em 25 de julho de 1943 o rei Vittorio Emanuele III assumiu o comando das forças armadas, destituiu Mussolini e o substituiu pelo marechal Badoglio, formador do novo governo. São estabelecidos acordos secretos com os Aliados e em 3 de setembro o general Castellano assinava a capitulaçáo das forças italianas (o "armistício curto"), anunciada somente no dia 8. Badoglio ordenou a cessaçáo das hostilidades contra as tropas americanas e declarou guerra à Alemanha, cujas divisóes

${ }_{5}^{5}$ FABRIS, Mariarosaria. O neo-realismo cinematográfico italiano: uma leitura. São Paulo: Edusp, 1996, p. 33-51. 
numerosas haviam se tornado exército de ocupação, enquanto o rei, a corte e os membros militares de seu governo abandonavam Roma e se refugiavam no sul, em Brindisi, já nas mãos dos Aliados. O país estava dividido. No sul libertado pelos Aliados, Badoglio governava em nome da Monarquia. O centro e o norte estavam ocupados pelas tropas nazistas. Para completar o legado de absurdos daquele fatídico mês, em 23 de setembro de 1943, Mussolini proclamou a República Social Italiana (RSI), que vigorou até 25 de abril de 1945. Durante essa chamada República de Salò o fascismo, em seus estertores, tornou-se ainda mais brutal e sanguinário. Enquanto isso, em Roma, o Comitato di Liberazione Nazionale (CLN), que unia os partidos antifascistas, não é reconhecido pelos anglo-americanos como governo legítimo, estatuto concedido apenas ao rei e ao marechal Badoglio.

Em 26 de setembro Badoglio assinou o "armistício longo", traduzindo a "rendiçáo incondicional" que o 3 de setembro tentara evitar. Noutro documento, os Aliados reconheciam a aliança com a Itália, desde que esta declarasse guerra à Alemanha, o que aconteceu em 13 de outubro. Depois disso, Vittorio Emanuele renunciou em favor do filho, Roma foi libertada em 4 de junho de 1944, com o avanço dos Aliados, cujo movimento decresce no centro da península durante o inverno de 1944-1945. A Resistência não recuou até abril de 1945, quando a "linha gótica" foi vencida. Em 28 de abril Mussolini foi executado após tentar uma fuga para a Suíça e, no dia 29, as tropas alemãs na Itália assinaram sua rendição. Terminava a luta pela libertação e, embora em ruínas, a Itália saía moralmente renovada dos fatos trágicos do período 1943-1945.

Esse intervalo fermenta posiçôes artísticas e intelectuais cujos efeitos serão vistos no país nos anos seguintes. É possível entender certas atitudes como algo semelhante a "tomar as rédeas" de um conhecimento histórico e de uma memória que, após o final do conflito, poderiam ser manipulados por uma visão oficializada, em nome de uma identidade nacional que falsificaria o passado. O papel desses artistas e intelectuais foi, essencialmente, o de assumir o desafio de fornecer narrativas e perspectivas sobre a história imediata, ainda que tratassem de assuntos indigestos e tocassem em problemas ainda presentes.

A narrativa italiana de 1930 é representada por novas posiçóes, mas é a partir de 1943 que o termo neorrealismo passa a se referir também à literatura, marcando uma relação sem precedentes entre essa forma de arte e o cinema. É possível detectar a necessidade de assumir a tendência realista, de fugir do clima hermético e especialmente de considerar elementos locais, regionais, de modo a transparecer o interesse pelo povo. Ideais antiburgueses e proletários se ajustavam a uma retórica urbana, frequentemente buscando a representação de realidades sufocadas pela ordem. Embora esse tipo de atitude caminhe numa direção progressista, há quem assinale nela características pequeno-burguesas, provincianas e politicamente moderadas. Isso poderia denotar uma dimensão populista, especialmente se lembramos que algumas geraçôes de intelectuais italianos assumiram um comportamento redentor, enquanto outras literaturas europeias negavam-se a desempenhar esse papel. 
“O ETERnO FASCISMO ITALIANO” E A RESISTÊNCIA DOS ROMANCES DE IGNAZIO Silone,

Nunca houve um manifesto neorrealista. Contar e ouvir a verdade nesse tipo de narrativa talvez tenham sido açóes que coincidiram com o desmantelamento de mistificaçôes fascistas, como as representaçóes herméticas e ambíguas apoiadas pelo regime. Seja como for, um dos preceitos neorrealistas seguido pelas narrativas aqui examinadas é o tratamento dos eventos como se o leitor pudesse se colocar na mesma perspectiva dos personagens. Tanto a voz memorialista quanto o narrador em terceira pessoa não estão muito interessados no realismo puro, nem mesmo numa repetição de ideais veristas. A narrativa neorrealista, de modo geral, revela a situação social e política que constrói a tragédia real dos grupos menos favorecidos.

Vários exemplos da narrativa italiana do século XX podem ser aproximados por constituírem relato de acontecimentos do centro-sul do país, seja no espaço da aldeia ou da capital de província, retomados como expressão da memória do período fascista. Embora a produção reflita diferentes momentos e enfoques distintos, a sociedade italiana sob o fascismo está reconstruída tanto por meio do ambiente camponês quanto da paisagem urbana, com personagens que podem ou não transitar entre esses cenários, incorporando tipos sociais do espaço rural, trabalhadores da terra, assim como operários, comerciantes, artesãos e desempregados da cidade. A forma narrativa, contudo, possui uma forma bastante agregadora, conforme destacou Patricia Peterle, ao se referir a certos romances produzidos entre as décadas de 1920 e 1940:

O relato dos narradores não é em nenhum momento dissociado da experiência do vivido; na verdade, a existência dos relatos é fruto de situaçôes apresentadas pelos personagens. Os testemunhos de Silone, Vittorini e Pavese, que se concretizam por meio da fala de seus personagens, podem ser vistos como tentativas de descrever algumas imagens opacas, que traçam os contornos dos espaços geográficos delineados da aldeia e da cidade (...). ${ }^{6}$

Com a ampliação de seus domínios, a historiografia tem favorecido linhas de pesquisa como a história das mentalidades, em que as sociedades são vistas a partir das suas representaçôes em determinados momentos históricos. Ao estimular o campo da história do imaginário, esse procedimento também pôde modificar o sentido do documento, categoria que passou a incluir fontes literárias escritas e orais, ilustraçôes, sons, imagens, assim como incorporou a crítica desse material, assumindo a análise das condiçôes de sua produção. A partir de obras como Fontamara, Cristo si è fermato a Eboli e Cronache di poveri amanti, capazes de avaliar com o substrato da memória a condição dos homens da terra e dos habitantes da cidade, para estabelecer a crítica do regime totalitário, pudemos estudar as relaçóes entre o texto literário, o momento da produção e as diferentes formas de recepção, entre as

6 PETERLE, Patricia. Ignazio Silone: encruzilhadas entre literatura, história e política. Niterói: Comunità, 2011, p. 119. 
quais a adaptação das obras para o cinema, realizadas, respectivamente, por Carlo Lizzani (1922-2013) em 1980, Francesco Rosi (1922) em 1979 e novamente Lizzani em 1953. Nos dois momentos, literário e audiovisual, a trama revela fenômenos que atravessam os tempos, como o sofrimento pela falta de meios e a repressão das liberdades, ao lado das formas de resistência.

Em momento de extrema lucidez, Carlo Levi (1902-1975) acrescenta à última terça parte do romance Cristo si è fermato a Eboli (Cristo parou em Eboli), que escrevia ainda sob o calor da hora, nos últimos anos da Segunda Guerra, uma reflexão preocupante sobre as forças que conjuravam para a perpetuação dos mesmos motores que haviam impulsionado o fascismo. Levi afirma que o regime deixará uma herança de revalorização das antigas ideologias (preponderantemente pequeno-burguesas, disseminadas por todas as camadas sociais) e de recriação de um Estado distante da vida, sacrossanto e abstrato. Mesmo que a transição para novas instituiçôes venha por meio de uma evolução lenta ou, ainda, pela violência ou por um movimento extremista, o "eterno fascismo italiano" deve se perpetuar sob novos nomes e novas bandeiras, de modo mais agravado. Essa constatação, de clara inspiração marxista, nos faz recordar algumas conclusóes sobre mecanismos histórico-sociais brasileiros e a sorte dos pobres, cujo destino estaria condenado a voltar ao ponto inicial, e a terminar piorado. Embora esta máxima simplista não traduza a complexidade dos processos históricos, é sintomático perceber que o intelectual italiano não se rende à perspectiva de tempos vindouros, especialmente devido ao que viu e viveu no sul do país, durante meados dos anos de 1930, época em que outro escritor e ativista importante, Ignazio Silone (1900-1978), encontrava-se exilado na Suíça e já havia escrito seu primeiro romance, com forte marca antifascista.

Fontamara de Silone tem um caráter coletivo, é quase perpassado por uma musicalidade coral e traz o conflito de classes sem credo ideológico. A narrativa reivindica a consciência das personagens que compartilham o conteúdo das memórias do autor. Escrito no exílio em 1930 e publicado em alemão em 1933,7 o romance retrata a vida camponesa de um povoado do sul da Itália, um universo que simula a sociedade naquele momento, e afronta os relatos produzidos pelo Estado e as dificuldades de publicação do romance. Fontamara possui três narradores originais cuja história é reorganizada pelo narrador principal, no difícil encargo de transformar "uma série de fatos imprevistos e incompreensíveis" em narrativa. Ao ouvir seus três visitantes, o homem exilado se surpreende e se identifica. Com base nessa moldura, Ignazio Silone reestrutura o ponto de vista para nebulizar a sua memória pessoal. A forma atingida revisa o gênero e alcança novos níveis de representação, mantendo a atualidade do romance, para além do regionalismo e do antifascismo.

\footnotetext{
7 A primeira edição de Fontamara teve traduçáo para o alemáo realizada por Nettie Sutro, e saiu pela editora Verlag Oprecht und Helbling, de Zurique. O romance é publicado em italiano ainda no exterior, pela Nuove edizioni italiane, de Paris-Zurich. De 1945 é a primeira publicação italiana, na revista Il Risveglio, de Roma. Depois Fontamara sai pela editora Faro, também de Roma, em 1947 e, em 1949, em edição revisada pelo autor, pela Mondadori, de Milăo. Para a maioria dos italianos, é um livro dos anos de 1940.
} 
“O ETERnO FASCISMO ITALIANO” E A RESISTÊNCIA DOS ROMANCES DE IGNAZIO Silone,

Carlo Levi compóe uma narrativa de memória entremeada de reflexáo histórica e sociológica, evocando o período de 1935-1936 e os cenários meridionais e problemáticos da Lucania, do confinamento como prisioneiro do regime fascista. ${ }^{8} \mathrm{O}$ intelectual manifesta na prosa uma consciência extravasada do momento presente ao manipular sua própria vivência da década anterior ao momento que escrevia, trazendo à tona problemas que agravam a severidade dos momentos decisivos da Segunda Guerra. Como narrativa híbrida, o romance de Levi é, ao mesmo tempo, relato objetivo e elaboração subjetiva equalizados numa forma literária. Escrito entre 1943 e 1944, Cristo si è fermato a Eboli (Cristo parou em Eboli) é testemunho do exílio e do mergulho do escritor nas consequências nefastas do regime. É possível ver uma incapacidade até certo ponto natural do filme homônimo de Francesco Rosi ao traduzir a síntese de tratamento literário e reflexão histórico-social. Por isso é necessário ler a adaptação como atitude sobre a matéria literária e resultado da experiência histórica. $\mathrm{O}$ caráter memorialístico se firma no artifício das cenas que aproveitam a abertura do livro, o curto monólogo de Levi, que assume o caráter de moldura da narrativa. A presença da pintura no filme materializa ainda mais intensamente as questôes sobre o absurdo contido nas telas, registros das pessoas.

O romance de Vasco Pratolini (1913-1991) revisita o passado através da recriação de um microcosmo florentino dos anos de 1920, durante a afirmaçáo do fascismo. O escritor autodidata escreve logo após o final da guerra, no momento favorecido pelo contexto democrático, o que talvez tenha determinado a operação épica de distanciamento e as influências do modelo populista de representação. Pratolini retorna aos anos da afirmação do regime fascista recorrendo à tradição medieval e historiográfica, mantendo como norteadores o olhar social e a memória de infância, vivida em Florença. Sob os efeitos do movimento intelectual da Resistência italiana, no contexto democrático da república parlamentar e do pluripartidarismo (1946-1948), o romance evidencia a perspectiva igualitária traindo o momento representado, quando a desesperança coroava a vida política e social. Em 1953, Carlo Lizzani filma sua adaptaçáo no fechamento dos horizontes com a restauração de forças conservadoras, diminuindo o foco visionário da narrativa e representando o passado a partir das desilusóes do presente.

Lizzani foi um dos mais profícuos homens de cinema formados durante o neorrealismo italiano, período de breve duração e controvertido, porém de extrema importância como impulso moral no cinema italiano. $\mathrm{O}$ diretor iniciou sua carreira como roteirista e assistente de direção dos mestres neorrealistas Giuseppe de Santis, Roberto Rossellini e Alberto Lattua$\mathrm{da}$, quando começou a praticar a nova linguagem que detinha boa parte do impacto causado pela escola neorrealista. Seu primeiro filme como diretor (Achtung! Banditi., 1951) se efetiva

\footnotetext{
8 O confinamento ao qual nos referimos (confino, em italiano) era uma medida policial adotada nos anos de 1930 para substituir a prisão domiciliar. Consistia em impor ao condenado a transferência por um determinado tempo para uma região distante da de sua residência ou de seu delito.
} 
com a necessidade de rever a Resistência italiana durante a Segunda Guerra, enquadrá-la num contexto histórico e social para entender alguns episódios do conflito.

A vocação da filmografia de Lizzani é o panorama histórico do período que vai do final do século XIX e cobre praticamente todo o século XX. Perseguindo a tentativa de apreender a complexidade de um mundo em pleno "breve século XX", vários filmes de Lizzani recorrem a romances, exemplos da apropriação do literário para produção de um novo significado no momento da realizaçáo cinematográfica, contexto que também é levado em conta na nova concepção estética até suas mais recentes produçôes. Se destacarmos desse panorama Cronache di poveri amanti (Carlo Lizzani, 1953) e Fontamara (Carlo Lizzani, 1978), tomamos a perspectiva do discurso histórico revisitado com olhares sobre o cotidiano, sobre os pequenos fatos do passado recuperados no presente da criação. Nos filmes que vieram dos romances de Vasco Pratolini e Ignazio Silone, ressaltamos a busca do diretor pela ação corálica, a temática popular disposta a relembrar os anos de Resistência e a preocupação com o indivíduo que viveu os anos do fascismo, itens caros para uma poética situada no limite entre a percepção histórica e a visão excessivamente emocional do passado.

Os filmes mapeiam os anos de 1920 e o impacto do regime fascista tanto no ambiente rural quanto no contexto citadino. Assim, o microcosmo de um vilarejo na região dos Abruzzo e de uma rua de Florença compóem a visão de Lizzani sobre os primeiros anos do fascismo, com acento humanizado. Revisitados pela linguagem sobre a qual incide a força de enquadramentos e da fotografia capazes de revigorar o sentido da produção consciente dos problemas imediatos, os filmes repensam o passado e os ideais antifascistas, ao mesmo tempo que discutem o presente através das analogias promovidas pela imagem e pelo discurso, dispostos a ir além dos desígnios políticos para assumir a responsabilidade de dar voz aos que não se manifestaram durante o percurso histórico, talvez para que a memória popular não seja constituída pelo que foi determinado pela história oficial, mas se torne o que é preciso que lembremos. O cinema de Carlo Lizzani pode ser estudado a partir de seus recursos hábeis em oferecer nova dimensão à representação literária, inclusive no que diz respeito à instrumentação midiática que permite o acesso à memória, à história e à consciência tanto dos populismos quanto dos revisionismos. Mais especificamente, as contradiçóes entre a ideologia dos intelectuais de esquerda e a exigência da classe operária, tão minuciosamente exploradas por Alberto Asor Rosa como forma de incompatibilidade entre o populismo estetizante de origem cultural burguesa e a militância operária, ${ }^{9}$ podem receber novas matizes, conforme é nossa intenção aqui.

Por outro lado, é possível dizer que a transposição do romance de Carlo Levi para o cinema pelas mãos de Francesco Rosi aproveita o registro da vida camponesa ligada ao ritmo da natureza, às superstiçóes, à magia elevada ao posto de ciência. Ao lado disso, se serve das

9 ROSA, Alberto Asor. Scrittori e popolo. Il populismo nella letteratura italiana contemporanea. Torino: Einaudi, 1988. 
cenas em que aparecem as necessidades reais, cuja soma é a marginalização das aldeias em relação ao restante do país e também da discrepância interna, quando mapeia a contradição entre os galantuomini a saborear biscoitos e os camponeses padecendo com a malária. $\mathrm{O}$ filme continua a rejeitar a imposição política e econômica pensada por Levi, mas amplia o espectro de relativização, a começar pela utilização da trilha sonora com canções fascistas a cançôes populares napolitanas, cujo efeito sobre o espectador inclui a passagem do tempo e as consequências de outras catástrofes. Sobressai uma consciência extremada através da verdade almejada pelos discursos compostos em tempos de crise. Nesse sentido, podemos dizer que o filme, realizado após as discussóes sobre o caráter populista da literatura neorrealista, tenta enfocar e ampliar a consciência que transborda do livro.

Segundo Lino Micciché, o conteúdo da trama traz à tona um mundo que aparentemente interrompe uma sucessão de radiografias do poder na insigne filmografia de Rosi. ${ }^{10}$ No entanto, o diretor que concebeu seus filmes como instrumentos de investigação e denúncia nos apresenta as nuances funestas e degradadas do poder em Cristo si è fermato a Eboli através do podestà, ${ }^{11}$ do cobrador de impostos, da atitude do governo ao libertar, em 1936, quando a confiança fascista aumentava graças ao avanço na Abissínia, o confinato "liberal" de Turim, Carlo Levi, enquanto mantinha detidos em confinamento os comunistas de Ancona e de Pisa. Mas o que fica latente é a incapacidade de ação do protagonista em várias cenas, coisa que chega a se confundir com a frustração que permanece no semblante cansado de um Carlo Levi que não encarna o mito redentor. Assim como no romance, as histórias não se resolvem, deixando várias interrogações e quase óbvias respostas a cargo do espectador, pois o protagonista não consegue dar solução para o desastre social.

Um dos episódios que encerram o filme refaz justamente a burocracia à qual o médico Levi se sujeita para ver um doente que sucumbe à morte na aldeia vizinha. Portanto, assim como é capaz de mostrar a torpeza, a manipulação, a corrupção pelos poderes, as memórias de Levi ainda atestam no final dos anos de 1970 a derrocada da utopia burguesa (segundo a qual a inserção na História seria suficiente para derrubar vícios primitivos). Nas palavras de Micciché, Rosi quer dizer que não basta mudar o poder, é preciso mudar a qualidade de sua lógica. ${ }^{12}$ Visto por outro ângulo, o diagnóstico também pode se tornar um convite à reação diferente dos temores e nostalgias a relacionar o presente ao passado de opressão e repressão.

O filme de Rosi já contava com a assimilação das ciências humanas e da psicanálise, fenômenos muito comuns após os anos 1960, quando o cinema atinge um grau de sofisticação, especialmente ao privilegiar a metáfora. Vale ressaltar que as discussóes sobre o caráter populista da literatura de autores neorrealistas também já estavam em pauta. Ainda assim, Rosi investiga o presente solidarizando-se corajosamente com as imagens de Carlo Levi,

\footnotetext{
${ }^{10}$ MICCICHÉ, Lino. Cristo si è fermato a Eboli. In: MICCICHÉ, Lino. Cinema italiano degli anni '70. Cronache 1969-1979. 2. ed. Venezia: Marsilio, 1989, p. 320.

${ }^{11}$ Chefe da administraçáo municipal (equivalente a prefeito) durante o regime fascista.

${ }^{12}$ MICCICHÉ, Lino. Cristo si è fermato a Eboli, op. cit., p. 321.
} 
recompondo-as de modo a validar sua finalidade e o sentido mais amplo daquele exílio. A leitura da obra literária determinou, sem dúvida, as escolhas do cineasta, porém alguns princípios da adaptação evidenciam recursos equivalentes, isto é, revelam procedimentos dispostos a formalizar em imagem visual a especificidade da forma literária, que inclui o revisionismo livre de receio de lutar contra obstáculos reais - e, portanto, mais sereno e ciente da falácia dos obstáculos fictícios.

Se há um elemento unificador das narrativas estudadas, podemos dizer que os três romances resgatam a verdade pela ação e expressão sem provincianismo e sem "aristocratismo alienador". ${ }^{13}$ Recordando a ótima expressão de Antonio Candido, cunhada durante a análise da repercussão da falta de meios materiais e das implicaçôes do subdesenvolvimento manifestada na literatura, vale utilizá-la para rever o pensamento de Asor Rosa, cuja ideia de estetização burguesa pode ser relativizada quando se leva em conta a necessidade da forma de representação. Assim, é preciso destacar que algumas produçôes brasileiras dos anos 1920 e 1930 combinaram cópia e rejeição de modelos num curioso processo de exaltação das diferenças locais, cujo resultado foi uma ilusão de independência. Como em quase todo o contexto latino-americano, houve um momento na literatura brasileira em que o exotismo era razáo de otimismo social, fase superada pela desmistificação do homem rústico por meio da convicção de que "quanto mais o homem livre que pensa se imbui da realidade trágica do subdesenvolvimento, mais ele se imbui da aspiração revolucionária". ${ }^{14}$ Um processo semelhante pode ser reconhecido no mergulho dos autores aqui estudados na realidade italiana dos anos 1920 e 1930.

Embora Ignazio Silone, Carlo Levi e Vasco Pratolini tenham pertencido a um sistema literário diferente do brasileiro, estiveram expostos a condiçōes históricas que pediam representação da miséria material e moral, e souberam expressar a consciência do atraso, incorporando na forma literária suas mais refinadas influências. Os autores não se utilizaram de uma realidade local para ressaltar-lhes a peculiaridade, não criaram formas "regionalistas" que reduziram os problemas humanos a elemento pitoresco, bem como náo fundaram certo "regionalismo" (supostamente afirmador de uma identidade nacional) baseado numa manifestação de exotismo inclinada a entreter a classe intelectual de várias outras culturas.

Ao determinar para em seguida misturar os tempos da escrita e dos fatos, os três romances passam a funcionar inevitavelmente em duas direções - repensam o passado e problematizam o presente —, mesmo com a situação de "exílio voluntário" do espírito no passado. Náo é demais ressaltar que a experiência particular dos autores se imbui de universalidade ao oferecer contribuiçấo ao debate de temas como a "questâo meridional" italiana e o subdesenvolvimento de outras partes do mundo, graças à consciência da realidade trágica

\footnotetext{
${ }^{13}$ CANDIDO, Antonio. Literatura e subdesenvolvimento. In: CANDIDO, Antonio. A Educação pela Noite e outros ensaios. 2. ed. São Paulo: Ática, 1989, p. 179.

${ }^{14}$ Ibidem, p. 186.
} 
movida e incorporada pela forma literária. ${ }^{15}$ Tal processo pode ser visualizado, guardadas as proporçôes, por meio de uma relaçáo de influência quando observamos a chegada e o impacto do neorrealismo cinematográfico italiano no Brasil ao final dos anos 1940. Acreditamos que, durante as décadas de 1950 e 1960, a influência da produção cultural italiana no Brasil foi especialmente manifestada no cinema, sem esquecer a fluência da música popular, marcadamente incorporada na Jovem Guarda. De qualquer modo, as relaçôes estabelecidas na produção cinematográfica foram mais importantes que as relações entre os dois países no terreno literário.

Filmes como Roma città aperta (Roberto Rossellini, 1945) souberam ajustar a necessidade de representaçáo à falta de meios sofisticados e de recursos do cinema moderno. Em razão disso, o entusiasmo na recepção do marco inaugural do neorrealismo no Brasil pode ser explicado não apenas como uma resposta contra as fórmulas banais das produçôes hollywoodianas, mas também como uma das consequências do entendimento do cinema italiano desse momento como renovação e redenção após o sofrimento da guerra. Um pouco mais tarde, o confronto com o cinema brasileiro surge de modo a permitir que a presença do cinema italiano entre nós acentue as deficiências das produçóes locais, especialmente por revelar a "evasão aos sacrifícios cotidianos" que os nossos filmes provocavam, como "algo que fizesse esquecer e não pensar, ao contrário das realizaçôes italianas". ${ }^{16}$ Mariarosaria Fabris destaca o período em que era lembrado pela crítica brasileira o fato de que a Itália fascista tinha vivido uma situação idêntica à nossa, mas que o neorrealismo surge logo após como "verdadeiro cinema", enquanto no Brasil a situação era outra, com produçôes medíocres. A recusa da produção nacional manifestada pela crítica, no entanto, também pode ter sido um reflexo da burguesia que não aprovava a imagem da realidade nacional nas telas. ${ }^{17}$ Rejeitado pela burguesia e pela intelectualidade, o cinema brasileiro passa por uma renovação capitaneada pela fundação da Vera Cruz em 1949 e pela ideia de afirmação de um cinema nacional, com base na qualidade do cinema estrangeiro. A despeito da trajetória da empresa e dos equívocos na classificação "neorrealista" empregada para designar filmes italianos do período, vale lembrar que o processo de influência do novo cinema italiano sobre críticos e cineastas brasileiros se consuma como expressão de cinema possível, sem grandes recursos e com altíssimo conteúdo humano, pelo menos desde os primeiros filmes de Nelson Pereira dos Santos e até o Cinema Novo.

No que diz respeito aos filmes que proporcionam uma leitura dos romances que estudamos, não podemos esquecer o fato de os diretores Lizzani e Rosi, formados na escola neorrealista, pertencem à segunda geração de cineastas do pós-guerra, cuja prática estética

\footnotetext{
${ }^{15}$ Ibidem, p. 158.

${ }^{16}$ FABRIS, Mariarosaria. A questão neo-realista e sua recepção no Brasil. In: FABRIS, Mariarosaria. Nelson Pereira dos Santos: um olhar neo-realista? São Paulo: Edusp, 1994, p. 41.

${ }^{17}$ A ideia é recuperada a partir da reflexáo de Jean Claude Bernardet, apud FABRIS, Mariarosaria. A questão neo-realista e sua recepção no Brasil, op. cit., p. 41.
} 
“O ETERnO FASCISMO ITALIANO” E A RESISTÊNCIA DOS ROMANCES DE IGNAZIO Silone,

e política se realizou ao longo dos anos do neorrealismo, justamente porque sua formação aconteceu junto aos grandes realizadores neorrealistas, para produzirem suas primeiras obras nos anos de 1950, após um aprendizado particularmente intenso e obrigatório. A geração de Lizzani e Rosi é de fundamental importância no legado para os cineastas da terceira e da quarta geração do pós-guerra, a saber, os realizadores cuja formação deve mais aos eventos de 1968 do que às memórias de guerra e sua outonada neorrealista, bem como os cineastas maduros no ambiente pós-revolucionário das décadas de 1970 e $1980 .^{18}$

No âmbito literário italiano do pós-guerra, podemos visualizar um avanço considerável nas formas de narrar o antifascismo, observando a superaçáo da reportagem, do relatório e mesmo do tom de denúncia trazido pela reprodução da verdade dos fatos. A criaçáo literária, nos três exemplos, tem a capacidade de atingir os leitores pela engenhosidade da trama, descrição dos espaços, passagem do tempo, construção das personagens e, sobretudo, pela construção do foco narrativo, capaz de encabeçar uma situação de passagem de autoridade em Fontamara, de reverberar as lembranças em primeira pessoa para recordar um período e um espaço diferente do tenebroso passado recente da Guerra, no caso de Cristo si è fermato a Eboli, e de recriar as manifestaçôes iniciais de intolerância fascista e de resistência à repressão em Cronache di poveri amanti.

\section{2.}

Ignazio Silone foi pseudônimo e posteriormente nome legal de Secondo (Secondino) Tranquilli, nascido na aldeia de Pescina em 1900 e falecido em Genebra, em 1978. Silone foi um escritor preocupado com a condição de seus conterrâneos da província de Aquila, região de Abruzzo, com a juventude abalada pelo devastador terremoto de 1915, no qual morreram vários familiares, inclusive a mãe então viúva. Logo em 1917 Silone partiu para Roma e se inscreveu na Unione Giovanile Socialista, mantendo a opção política que fizera pouco tempo antes, ao defender os camponeses. Participou da fundação do Partido Comunista d'Italia, sofreu prisôes e viveu no exílio em diferentes períodos. Após significativa participação nas atividades do partido, é expulso sob acusação de ser trotskista, em 1931. Permaneceu na Suíça desde 1930, produziu diversos romances e ensaios, tendo voltado a viver na Itália em 1944. Foi eleito em 1946 pelo PSIUP (Partito Socialista Italiano dell’Unità Proletaria). ${ }^{19}$

${ }^{18}$ MARCUS, Millicent. Italian Film in the Light of Neorealism. New Jersey: Princeton, 1986, p. 339.

${ }^{19}$ Há cerca de 25 anos, Dario Biocca e Mauro Canali, especialmente, foram responsáveis pelo retorno de uma questão delicada, a acusação de espionagem que recaiu sobre Ignazio Silone, que teria trabalhado para a OVRA (Organizzazione per la Vigilanza e la Repressione dell'Antifascismo), infiltrado no Partido Comunista - hipótese negada por muitos intelectuais, entre os quais Norberto Bobbio, e que, por falta de comprovação da atividade suspeita ou das informaçóes fornecidas, não se sustentou. Sabe-se apenas que o escritor teve contato com membros da polícia fascista quando o irmão esteve preso. Ver, sobre a acusação, BIOCCA, Dario. Ignazio Silone e la polizia politica. Storia di un "informatore". Nuova Storia Contempora- 
“O ETERnO FASCISMO ITALIANO” E A RESISTÊNCIA DOS ROMANCES DE IGNAZIO Silone, Carlo Levi e Vasco Pratolini

Gabriela Kvacek Betella

O primeiro romance de Ignazio Silone é escrito nas condiçóes de exílio, no período em que o autor vivia em Davos. O livro conta a realidade de uma regiáo de montanha, de um lugarejo de Marsica, sub-regiáo de Abruzzo, dominado pela pobreza e povoado por camponeses (ou cafoni), durante os primeiros anos do período fascista. O contexto é muito próximo do ambiente de criação do autor, por isso registra imagens da memória. A narrativa tem como ponto de partida o encontro imaginado entre o autor e uma família de fontamareses recém-chegados da Marsica, em busca do conforto do conterrâneo ilustre, para lhe contar os fatos recentes do vilarejo. O autor, homem letrado, se depara com a família de Fontamara constituída de um casal e um filho jovem. Os três pouco ou nada afeitos à palavra são, na verdade, narradores internos que carregam os hábitos de uma sociedade camponesa: os homens, costumeiramente, trabalham o dia todo nos campos e cultivam as suas terras pouco produtivas de montanha, para alimentar suas famílias com as colheitas; as mulheres se ocupam das casas e dos filhos, e só encontram os homens à noite. Poucos falam, quase ninguém sabe ler.

Normalmente, Fontamara é considerado romance representativo do neorrealismo literário, por assumir diversas características inovadoras na expressão, como a estrutura "a três vozes", construída sobre o fato de ser um relato dirigido ao autor, que o reproduz. A presença discreta do narrador-autor e a reelaboraçáo do discurso indireto livre foram recursos bastante utilizados pelos escritores italianos nos anos de 1940. A qualidade fundamental do primeiro romance de Silone é a sua criatividade na manipulaçáo da forma ainda em 1930, quando o livro começa a ser escrito. No caso de Fontamara, o narrador que apresenta a obra exerce sua autoridade, permitindo o acesso do leitor a uma regiáo praticamente escondida dos próprios italianos. O tom de abertura revela algumas intenções:

Os estranhos fatos que vou contar aconteceram durante um verão em Fontamara.

Dei esse nome a um lugar antigo e escuro, de camponeses pobres, situado na Marsica, ao norte do lago drenado do Fucino, no interior de um vale, entre as colinas e a montanha. Soube, mais tarde, que outros lugares da Itália meridional, em alguns casos com pequenas variantes, tinham o mesmo nome e, fato mais grave, apurei que os mesmos acontecimentos estranhos, fielmente contados neste livro, ocorreram em outros lugares, ainda que em época e sequência diferentes. Pareceu-me, porém, que isso não fosse motivo suficiente para que a verdade fosse silenciada. ${ }^{20}$

nea, n. 3, p. 67-93, 1998 e BOCCA, Dario. “Tranquilli (nell'ombra)”. Ignazio Silone in Francia. Nuova Storia Contemporanea, n. 3, p. 53-76, 1999; CANALI, Mauro. Il fiduciario Silvestri. Ignazio Silone, i comunisti e la Polizia politica. Nuova Storia Contemporanea, n. 1, p. 61-86, 1999. Giuseppe Tamburrano publicou dois livros importantes na tentativa de elucidar o episódio e a falta de provas: TAMBURRANO, Giuseppe. Il "caso Silone". Torino: UTET, 2006 e TAMBURRANO, Giuseppe. Processo a Silone. La disavventura di un povero cristiano. Bari: Lacaita, 2001.

${ }^{20}$ SILONE, Ignazio. Fontamara. Trad. Doris Cavallari. São Paulo: Berlendis \& Vertecchia, 2003, p. 19.

Gli strani fatti che sto per raccontare si svolsero nel corso di un'estate a Fontamara. 
“O ETERnO FASCISMO ITALIANO” E A RESISTÊNCIA DOS ROMANCES DE IGNAZIO Silone,

O narrador busca, por meio da revelação de que vários lugares da Itália meridional têm o mesmo nome e passam pelos mesmos "acontecimentos estranhos", externar uma situação conhecida por uma experiência de vida inteira. Com as consideraçóes de que os fatos comuns a vários lugarejos são "fielmente contados" e não haveria motivo para silenciar a verdade, o narrador estende seu apelo ao leitor. Com a invenção da trama, a partir da passagem da narrativa aos três narradores, o procedimento suaviza qualquer manifestação panfletária e aposta na forma literária. Assim, ao mesmo tempo que é capaz de ceder a posição de narrador para os camponeses, o homem letrado assume o posto do intelectual preocupado com as suas origens, enquanto narrador e como homem exilado. O casal que Silone imagina ouvir conta os fatos nos quais esteve envolvido, cada um com seu ponto de vista. Marido e mulher alternam-se em boa parte da condução da história, e o filho assume a perspectiva dos fatos na última parte, quando está ao lado do protagonista a empreender uma viagem. No efeito conseguido por Silone, o autor permanece como um estrangeiro na narrativa, sem tecer comentários explícitos.

O nome do vilarejo nasce de um dos mais graves problemas que afligem seus habitantes, a falta de água. Daí "fonte" / "amara" ("amarga") traduzir o sofrimento. Quando o fascismo chega ao poder, a cidade já era atravessada por problemas, o primeiro deles era a falta de luz, já que os fontamareses nunca haviam pagado uma conta, considerando que o fornecimento fosse uma coisa natural. $\mathrm{O}$ desvio do curso de água para as terras dos ricos proprietários, que inicia o segundo capítulo, narrado pela mulher, determina uma mudança nos personagens, a indignação e o desejo de se rebelar tornam-se comuns e as açóes coletivas são tomadas. Cada um passa a se ocupar dos problemas que dizem respeito a todos, e a coralidade das cenas faz com que os efeitos das situaçôes constrangedoras sejam ampliados para se visualizar a ambiência da revolta e a diferença entre os interesses dos camponeses e dos homens que exercem algum poder, de astúcia ou de cultura. Em algumas passagens, fica evidente o desejo de justiça sufocado pela própria inabilidade com os trâmites legais, com a linguagem ou com as atitudes.

O protagonista de Fontamara é Berardo Viola, um jovem forte e impulsivo, sempre pronto a se sacrificar pelos outros. Ele também é um camponês, porém perde a única terra que tinha. Berardo se apaixona por Elvira, e quer se casar. Como não tem terra nem trabalho, decide mudar de atitude e pensar em seus próprios interesses, na futura família, procurando evitar as brigas e discussôes. Quando a questão da água aparece, e é trazido à luz o embuste sobre a comunidade, todos esperam que Berardo intervenha, ainda que seja com

Ho dato questo nome a un antico e oscuro luogo di contadini poveri situato nella Marsica, a settentrione del prosciugato lago di Fucino, nell'interno di una valle, a mezza costa tra le colline e la montagna. In seguito ho risaputo che il medesimo nome, in alcuni casi con piccole varianti, apparteneva già ad altri abitati dell'Italia meridionale, e, fatto più grave, ho appurato che gli stessi strani avvenimenti in questo libro con fedeltà raccontati, sono accaduti in più luoghi, seppure non nella stessa epoca e sequenza. A me è sembrato però che queste non fossero ragioni valevoli perché la verità venisse sottaciuta. SILONE, Ignazio. Fontamara. Int. Aurelio Picca. Roma: Newton Compton, 2010, p. 27. 
“O ETERnO FASCISMO ITALIANO” E A RESISTÊNCIA DOS ROMANCES DE IGNAZIO Silone,

a violência. Contudo, seu projeto é passar um tempo em Roma, encontrar ali um trabalho, ganhar bastante dinheiro para readquirir a terra e casar com Elvira. E, de fato, parte na companhia do jovem que será o terceiro narrador da trama, a assumir o relato no capítulo VIII. Os dois não chegam a encontrar emprego, pois não possuem uma carteira de trabalho, necessária para serem admitidos. Berardo persevera, faz sacrifícios, até um dia receber um telegrama comunicando a morte de Elvira, que havia feito uma peregrinação e não aguentara a fadiga. Diante da notícia, Berardo se dá conta de que seus propósitos não têm mais sentido, náo precisa permanecer em Roma nem encontrar um trabalho estável. Uma reviravolta no personagem acontece, e novamente ele está disposto a se sacrificar pelas causas dos outros.

Fontamara parece conter um apelo implícito à análise das diferenças sociais, tanto no contexto específico e nas condiçôes da época marcada pela afirmação do regime autoritário, quanto na extensão espacial e temporal do romance. Berardo Viola personifica a obstinação da resistência, através da força física sempre à procura de provas mais árduas, à qual corresponde uma força de alma, uma capacidade de resolver e uma tenacidade que não o deixa dobrar-se mesmo diante da malignidade da sorte e da maldade dos homens. Berardo não cai, ainda diante da tortura, não se desvia da linha de conduta autoimposta.

O romance, por sua vez, é composto com eventos escolhidos de acordo com sua preponderância numa realidade psicológica que reconstitui o passado com base numa experiência do presente. A memória coletiva sempre manteve uma dimensão política, ao menos ideológica. Nas últimas décadas, novas visôes sobre as identidades nacionais têm repensado esses processos. Algumas estratégias revisionistas desenvolvem posturas capazes de relativizar os crimes cometidos pelo nazismo, por exemplo, como uma espécie de suspensão de rancores do passado em nome de uma harmonia nacional para o presente. ${ }^{21}$ Assim, a memória (da guerra, dos anos do fascismo italiano, da Resistência) pode ser manipulada com a responsabilidade de redirecionar a representação. Além disso, os mecanismos de reconstrução do passado aliam-se a desígnios políticos específicos de uma determinada época, provocando fenômenos do tipo da desmistificação de uma cultura fascista graças à literatura antifascista capaz de reposicionar as coisas de modo a chamar a atençáo para o que precisa ser lembrado.

Ignazio Silone volta ao passado recente, à afirmação do fascismo, às açôes abomináveis e, sobretudo, ao abandono das populaçôes do sul do país e à repressão de pensamentos supostamente contrários ao regime. Na condição de punido pelos representantes do Estado fascista e herdeiro das memórias das desigualdades agravadas, o discurso de Silone representa o compromisso com as populaçóes esquecidas. Tudo isso aflora nas linhas de Fontamara, num relato vivaz que denuncia a proximidade no tempo entre os acontecimentos e o romance: a narrativa se baseia em incidentes de que o autor de fato teria tido notícia, a despeito de conter elementos colhidos das lembranças de juventude.

\footnotetext{
${ }^{21}$ BEN-GHIAT, Ruth. Fascism, Writing, and Memory: The Realist Aesthetic in Italy, 1930-1950 The Journal of Modern History, v. 67, n. 3, p. 627, Sep. 1995.
} 
“O ETERnO FASCISMO ITALIANO” E A RESISTÊNCIA DOS ROMANCES DE IGNAZIO Silone, Carlo Levi e Vasco Pratolini

Gabriela Kvacek Betella

O ponto de partida da trama é a narrativa das atrocidades cometidas pelo menos desde 1927 (coincidentemente mais graves à medida que o regime fascista se estrutura) por várias instâncias do poder na aldeia da região de Abruzzo. Desde o prefácio de Fontamara, somos apresentados às descriçôes dos ambientes rústicos e ao sofrimento resultante de privações:

A maior parte daqueles casebres só tem uma abertura, que serve de porta, de janela e de chaminé. Em seu interior, quase sempre de terra batida e paredes sem reboco, moram, dormem, procriam, às vezes no mesmo cômodo, homens, mulheres, seus filhos, cabras, galinhas, porcos, burros. As exceçôes reduzem-se a uma dezena de casas de pequenos proprietários e a um antigo sobrado desabitado e em ruínas. (...)

Aos que veem Fontamara de longe, do Distrito do Fucino, o povoado parece um rebanho de ovelhas escuras e o campanário, um pastor. Uma aldeia, enfim, como muitas outras; mas para quem ali nasce e cresce, o cosmos. Toda a história universal passa-se lá: nascimentos, mortes, amores, ódios, invejas, lutas, desesperanças.

(...)

Por vinte anos o mesmo céu, circunscrito pelo anfiteatro natural das montanhas que encerram o Distrito em uma barreira intransponível; por vinte anos a mesma terra, as mesmas chuvas, o mesmo vento, a mesma neve, as mesmas festas, as mesmas comidas, as mesmas angústias, as mesmas penas, a mesma miséria: a miséria recebida dos pais, que a haviam herdado dos avós, e contra a qual o trabalho honesto nunca serviu para nada. (...)

Primeiro vinha o plantio, depois a adubação, depois a colheita, depois a vindima. E depois? Depois tudo de novo. O plantio, o cultivo, a poda, a adubação, a colheita, a vindima. Sempre a mesma canção, o mesmo refrão. Sempre. ${ }^{22}$

O espaço aparece metrificado pela descrição. O tempo vem medido pela repetição, enquanto os personagens são mostrados pela escala social. Tais elementos da narrativa, já dis-

22 SILONE, Ignazio. Fontamara, op. cit., 2003, p. 20-21.

La maggior parte di quelle catapecchie non hanno che un'apertura che serve da porta, da finestra e da camino. Nell'interno, per lo più senza pavimento, con i muri a secco, abitano, dormono, mangiano, procreano; talvolta nello stesso vano, gli uomini, le donne, i loro figli, le capre, le galline, i porci, gli asini. Fanno eccezione una decina di case di piccoli proprietari e un antico palazzo ora disabitato, quasi cadente. (...)

A chi guarda Fontamara da lontano, dal Feudo del Fucino, l'abitato sembra un gregge di pecore scure e il campanile un pastore. Un villaggio insomma come tanti altri; ma per chi vi nasce e cresce, il cosmo. L'intera storia universale vi si svolge: nascite morti amori odii invidie lotte disperazioni.

(...)

Per vent'anni il solito cielo, circoscritto dall'anfiteatro delle montagne che serrano il Feudo come una barriera senza uscita; per vent'anni la solita terra, le solite piogge, il solito vento, la solita neve, le solite feste, i soliti cibi, le solite angustie, le solite pene, la solita miseria: la miseria ricevuta dai padri, che l'avevano ereditata dai nonni, e contro la quale il lavoro onesto non è mai servito proprio a niente. (...)

Prima veniva la semina, poi l'insolfatura, poi la mietitura, poi la vendemmia. E poi? Poi da capo. La semina, la sarchiatura, la potatura, l'insolfatura, la mietitura, la vendemmia. Sempre la stessa canzone, lo stesso ritornello. Sempre. SILONE, Ignazio. Fontamara, op. cit., 2010, p. 28-29. 
“O ETERnO FASCISMO ITALIANO” E A RESISTÊNCIA DOS ROMANCES DE IGNAZIO Silone,

postos desde o prefácio, integram o preâmbulo da pintura do ambiente e do relato das possíveis açôes. Com essa antecipação, o leitor sente-se instigado a ler, na expectativa de saber mais sobre os "estranhos fatos" que, no fundo, não serão estranhos aos que tiverem alguma interface de memórias. Conforme se pode ler em Fontamara, as "injustiças mais cruéis eram tão antigas que haviam adquirido a naturalidade da chuva, do vento, da neve". ${ }^{23}$ Contrapóem-se a força das misérias coletivas e o represado sentimento de revolta, cuja instância faz o discurso do narrador incorporar as vozes caladas.

Como condenados a cavar suas próprias covas em silêncio, nos arredores de Fontamara os cafoni deviam ainda trabalhar na terra cujos frutos nunca seriam melhores e, como se não bastasse, deveriam consumir eles mesmos o produto ruim dos vinhedos, infestados por doenças. Por outro lado, aos cidadáos de regiôes distantes "das Fontamaras", o efeito buscado pelas imagens e fatos do romance é a revelação das desigualdades, das arbitrariedades, da anulação dos seres humanos. Há momentos de efeito bastante forte nas descrições do prefácio, como vimos. O homem letrado escreve visivelmente impactado pelas histórias que tinha ouvido, e compóe algumas notas introdutórias para situar o leitor no espaço e nas condiçóes de vida. Mais que isso, a narrativa cria imagens dispostas a particularizar a região, ao mesmo tempo que a capacidade de representaçáo as universaliza:

Os fontamareses vestem-se como os miseráveis de qualquer região do mundo. E em Fontamara não há bosque: a montanha é árida, nua, como a maior parte dos Apeninos. Os pássaros são raros e amedrontados pela caça indiscriminada de que são vítimas. Não há rouxinóis; no dialeto local não existe sequer uma palavra para designá-los. Os camponeses não cantam, em coro ou sozinhos; nem quando estão bêbados e, muito menos (e é compreensível), quando vão para o trabalho. Em vez de cantar, blasfemam de bom grado. ${ }^{24}$

Deve-se observar com cuidado o procedimento de Silone. O caráter de universalidade parece ofuscar as particularidades locais. Fato que não merece ser esquecido é a capacidade de manipulação literária da realidade imediata, a saber, a presença viva da aldeia na composição e em toda a textura do romance. Assim, a representação artística só se formaliza quando os aspectos mais particulares se manifestam. Antes de qualquer proclamação de narrativa universal, moderna ou mesmo pós-moderna, o primeiro romance de Ignazio Silone está

\footnotetext{
${ }^{23}$ SILONE, Ignazio. Fontamara, op. cit., 2003, p. 21.

Le ingiustizie più crudeli vi erano così antiche da aver acquistato la stessa naturalezza della pioggia, del vento, della neve. SILONE, Ignazio. Fontamara, op. cit., 2010, p. 29.

${ }^{24}$ SILONE, Ignazio. Fontamara, op. cit., 2003, p. 27.

I Fontamaresi vestono come i poveracci di tutte le contrade del mondo. E a Fontamara non c'è bosco: la montagna è arida, brulla, come la maggior parte dell'Appennino. Gli uccelli sono pochi e paurosi, per la caccia spietata che a essi si fa. Non c'è usignolo; nel dialetto non c'è neppure la parola per designarlo. I contadini non cantano, né in coro, né a soli; neppure quando sono ubriachi, tanto meno (e si capisce) andando al lavoro. Invece di cantare, volentieri bestemmiano. SILONE, Ignazio. Fontamara, op. cit., 2010, p. 35.
} 
mais plantado em seu país (embora tenha sido escrito no exterior) do que na tradição literária ocidental, ainda que seja introduzido por um "prefácio fabuloso", a explicar e justificar o sentido de "fábula" criado por Silone. No terreno da forma, a criação ficcional apoiada na trama engenhosa mascara o autor e sua voz com todas as vozes do romance. Procedimento louvável e disfarce criativo para o homem exilado que insistia em atuar na denúncia dos problemas de sua terra.

\section{3.}

Carlo Levi relata uma experiência pessoal de prisão política, de exílio em seu próprio país. Confinato na aldeia de Grassano e depois na de Aliano (ambas na região da Lucania, nome que se sobrepóe ao de Basilicata), ${ }^{25}$ o jornalista, escritor, médico, pintor e político cumpria a medida policial e permaneceu na Lucania de 1935 a 1936, percebendo não somente a distância espacial como também os resultados do abandono da regiáo pelo resto do país e o avanço das pretensôes do regime, pois o final de seu exílio acontece graças à vitória do exército de Mussolini na Albânia. O título do livro retoma a expressão utilizada pelos lucanos para definir a dimensáo do abandono: até Cristo teria parado em Eboli (cidade da regiáo da Campania, província de Salerno), sem querer chegar a alguns dos locais mais miseráveis do extremo sul da Itália.

Levi soube transitar de um ambiente a outro e aproveitar as experiências. Nascido em Turim em 1902, de família judia, uma de suas primeiras atividades jornalísticas data de 1922, no jornal Rivoluzione liberale, fundado por Piero Gobetti, em tempos de consolidação de ideias socialistas que pregavam a aproximação aos problemas do sul do país. Nessa época Levi também se iniciava na pintura e cursava medicina, em que se formou em 1924. Do periódico de número único Lotta Politica, publicado clandestinamente em Turim, ao programa revolucionário do declarado antifascista Quaderni di giustizia e libertà, os ensaios de Levi trazem reivindicaçôes de reformas sociais e questóes para o problema meridional, além da discussão sobre a autonomia, princípio fundador da revolução italiana, que deveria seguir a queda do fascismo. Depois das prisóes dos anos 1930, Levi voltou à atividade política na década seguinte. Conviveu praticamente com todos os intelectuais e escritores italianos do período. Foi senador por dois mandatos e faleceu em 1975. Foi sepultado em Aliano.

\footnotetext{
${ }^{25}$ Para estrangeiros, normalmente o nome Lucania também designa a região da Basilicata, situada entre a Calabria (ao leste), a Campania (ao norte) e a Puglia (a oeste). No entanto, a primeira denominaçáo remonta a um período anterior à conquista pelos romanos, quando se referia a um território mais amplo, incluindo partes da Calabria e da Campania. A regiáo passou a se chamar Basilicata a partir do século XIII e oficialmente mantém este nome até hoje, à exceção do período entre 1932 e 1947, quando voltou a se chamar Lucania, nome que uma parte significativa dos habitantes da região preferem, por razóes ligadas às suas origens e à própria história.
} 
“O ETERnO FASCISMO ITALIANO” E A RESISTÊNCIA DOS ROMANCES DE IGNAZIO Silone,

Em 1963, Carlo Levi escrevia ao editor Giulio Einaudi para comentar a nova edição do livro escrito vinte anos antes. Declarava sua consciência da reelaboração dos fatos descritos, pois desenvolvera "com o auxílio da memória, não apenas os acontecimentos do passado, mas também a contemporaneidade infinita e poética dos tempos e dos destinos". ${ }^{26} \mathrm{Em}$ seu "rifugio alla morte feroce" em 1943-1944 a memória dos anos de 1935-1936 se tornava uma forma de enfrentamento da matéria trágica, caótica e catastrófica que se punha diante do escritor. $\mathrm{O}$ livro era uma defesa confessa, mas cerca de trinta anos depois do vivido o autor ainda pode concluir que o momento da escrita também havia sido uma forma de reviver o outro "eu", aquele que descobrira "a história além da história, o tempo fora do tempo, a dor antes de nada mais, e a si mesmo" ${ }^{27}$ por meio da reformulação da experiência que o levou à Lucania.

Conforme foi dito, Cristo si è fermato a Eboli vem de uma experiência de exílio em Grassano e depois Aliano, que assume no livro o nome de Gagliano, provavelmente na tentativa de assumir na grafia uma pronúncia e, com isso, destacar a importância do período passado nessa segunda aldeia. A narrativa também não apresenta na sua parte inicial a chegada do narrador à primeira cidade de confinamento - o início do livro apresenta as impressôes sobre Gagliano. A situação criada pelo discurso permitiu que as lembranças de Grassano invadissem o relato como uma curiosa rememoraçáo dentro de outra narrativa do passado - procedimento que ocorre mais de uma vez, quando o narrador faz uma digressáo e volta no tempo enquanto relembra um momento de reflexão, por exemplo. $\mathrm{Na}$ "memória dentro da memória" o narrador descreve os arredores de Grassano como se tentasse fixar a paisagem mais firmemente à memória e ao texto, como uma declaração de carinho numa despedida, ao se deslocar para a segunda cidade, ou ainda tenta associar pessoas e hierarquias de poder de Grassano aos sujeitos de Gagliano. A certa altura, quando o narrador nos conta sobre o retorno a Grassano, finalmente sabemos algo sobre a primeira cidade e a chegada do confinado meses antes:

Tinha chegado lá após meses de solidão absoluta. Lá tornara a ver, pela primeira vez, as estrelas e a lua, as plantas e os animais, bem como o rosto dos homens. Assim, Grassano tinha ficado impressa na minha mente como uma terra de liberdade. ${ }^{28}$

\footnotetext{
${ }^{26}$ LEVI, Carlo. Cristo parou em Eboli. Trad. Wilma F. Ronald de Carvalho. Rio de Janeiro: Nova Fronteira, 1986, p. 5.

(...) sul filo della memoria, non solo gli avvenimenti del passato, ma la contemporaneità infinita e poetica dei tempi e dei destini (...). LEVI, Carlo. Cristo si è fermato a Eboli. 17. ed. Torino: Einaudi, 2003, p. XVII. ${ }^{27}$ LEVI, Carlo. Cristo parou em Eboli, op. cit., p. 7.

(...) la storia fuori della storia, e il tempo fuori del tempo, e il dolore prima delle cose, e se stesso (...). LEVI, Carlo. Cristo si è fermato a Eboli, op. cit., 2003, p. XVIII.

${ }^{28}$ LEVI, Carlo. Cristo parou em Eboli, op. cit., 1986, p. 188-189.

(...) ci ero arrivato dopo mesi di solitudine assoluta; là avevo riveduto per la prima volta le stelle e la luna e le piante e gli animali e il viso degli uomini: mi si era cosí fissata nel ricordo come una terra di libertà. LEVI, Carlo. Cristo si è fermato a Eboli, op. cit., 2003, p. 141.
} 
“O ETERnO FASCISMO ITALIANO” E A RESISTÊNCIA DOS ROMANCES DE IGNAZIO Silone,

O livro de Carlo Levi é produzido num tempo em que se fazia necessário narrar, melhor dizendo, no tempo em que os registros do que dizia respeito à destruição material e humana de uma guerra eram legitimados por um veículo artístico. O período era decisivo e - particularmente na Itália - de intensas reviravoltas e grande tensão, devido à divisão de forças no país e à violência instaurada. Contudo, o autor não trata do presente. A frase de abertura, "Passaram-se muitos anos, cheios de guerra e do que se costuma chamar de História" 29 destaca o tempo que separa o presente da composição do passado dos fatos narrados. Define logo nas primeiras linhas o seu processo e as condiçốes sob as quais póe em prática a empreitada da memória:

(...) fechado numa sala, um mundo fechado, é agradável retornar, através das lembranças, àquele outro mundo, encerrado no sofrimento e nos costumes, este mundo à margem da História e do Estado, eternamente paciente, onde o camponês vive, na miséria e no afastamento, a sua vida imóvel numa terra árida, diante da morte. ${ }^{30}$

Ao longo da narrativa, no exercício de retrocesso no tempo, esse narrador prova novamente o gosto da acolhida durante a qual os conceitos do homem do norte náo valem muito no mundo que concentra uma força histórica tremenda, capaz de provocar a reflexão sobre outras realidades e, certamente, de potencializar os problemas. É justo deduzir que o momento de narrar pedia uma atitude que aliasse o ponto de vista aos acontecimentos imediatos, mas também pode ser legítimo reconhecer a capacidade do discurso memorialístico de ampliar o espectro das reflexôes.

Ao localizar os tempos da escrita e dos fatos, o texto passa a funcionar inevitavelmente nas duas direçôes, mesmo com a situação de "exílio voluntário" do espírito no passado. Não é demais concluir que, além de uma experiência particular imbuída de universalidade ao oferecer contribuição ao debate sobre o subdesenvolvimento, a forma literária elimina as diferenças entre a voz que narra (que revela, contudo, o preparo do intelectual engajado) e as vidas narradas.

A escrita das memórias revisita as impressóes do exilado através das diversas histórias de habitantes locais, camponeses que desenham um painel de homens e mulheres mostrando as razões da emigração, a exclusão dessa população pelo Estado, o misticismo religioso, as péssimas condições de saúde. De um modo geral e panorâmico, a obra cumpre uma função

${ }^{29}$ LEVI, Carlo. Cristo parou em Eboli, op. cit., 1986, p. 11.

Sono passati molti anni, pieni di guerra, e di quello che si usa chiamare la Storia. LEVI, Carlo. Cristo si è fermato a Eboli, op. cit., 2003, p. 3.

${ }^{30}$ LEVI, Carlo. Cristo parou em Eboli, op. cit., 1986, p. 11.

(...) chiuso in una stanza, e in un mondo chiuso, mi è grato riandare con la memoria a quell'altro mondo, serrato nel dolore e negli usi, negato alla Storia e allo Stato, eternamente paziente; a quella mia terra senza conforto e dolcezza, dove il contadino vive, nella miseria e nella lontananza, la sua immobile civiltà, su un ruolo arido, nella presenza della morte. LEVI, Carlo. Cristo si è fermato a Eboli, op. cit., 2003, p. 3. 
“O ETERnO FASCISMO ITALIANO” E A RESISTÊNCIA DOS ROMANCES DE IGNAZIO Silone,

semelhante à do painel "Lucania '61", pintado por Levi como uma releitura do seu próprio livro, no sentido de dar conta de um universo verdadeiro, imediato, palpável, apenas entrevisto pelo pensamento teórico. A narrativa, por sua vez, parece mapear toda a regiáo, explorar o tempo através das descriçôes de mudanças de estação e anular a primeira pessoa do discurso através de uma diluição promovida pelos momentos descritivos que contaminam o texto. Portanto, assim como a pintura não torna as imagens necessariamente didáticas ao misturá-las como num amálgama em movimento de cenas, cenários e pessoas, o texto condensa e traduz a experiência numa espécie de "travelling intertemporal" capaz de dialogar com as técnicas do audiovisual que resultam na simultaneidade e nas atualizaçóes e que podem revelar a ânsia pelo registro e a necessidade do apelo constante à memória. Curiosamente, o filme de Francesco Rosi, baseado no relato de Levi, náo aproveita esse tipo de registro com quebras tempo-espaciais.

Trabalhando com a matéria da experiência o autor preserva sua reflexão, num certo sentido, dos horrores da guerra presente, porque essa matéria não pode ser retirada pela imposiçáo, nem saqueada, nem retida. $\mathrm{O}$ estilo de narrar transcende o mero relato passivo de lembranças e é atrativo, pois reelabora as imagens da memória durante o próprio ato da narração, daí a vivacidade impressionante. A dramaticidade do discurso de Carlo Levi é sutil, mascarada pelo caráter ensaístico que parece se colocar no tom certo. Náo há marcas de romanesco, contudo, existe o poder de sedução de um romance. Boa parte dessa atração está associada à micro-história traçada pelo cotidiano da Lucania. A perspectiva da descoberta não esmorece com os verbos no passado — assim como o narrador permanece surpreso, por vezes assustado, o leitor também estranha aquele território tão longe do progresso civil, tão destacado e tão encravado no país que traça a sua história e sua glória com as guerras, mantendo incoerências. Tal perspectiva é sabiamente utilizada, uma vez que o leitor se aproxima dos fatos sem deixar de estar consciente da mediação.

O narrador recompóe a perplexidade vivida naquele momento em que presenciava a miséria com a presentificação das impressões de luz e sombra, de sensaçôes táteis. Levi traz para o momento que vivia durante a composição do livro imagens nada consoladoras, posto que agravantes de uma aflição e do absurdo da desumanização compulsória. Destaca a impotência e agrava seu sentido com as imagens de abandono, de desolação. As descrições de Levi testemunham porque desejam resgatar o que há de mais terrível, o que dá a impressão de ter permanecido na época em que se narra.

Ainda que seja pela narrativa fragmentada, voltar ao modo de vida daquela sociedade arcaica e aos sistemas de repressão que atravessaram os tempos é revelar, de certo modo, uma face única infelizmente disposta a atravessar o milênio, conforme já profetizava Carlo Levi, de certo modo revisando nos anos de 1940, em plena presença da guerra, suas próprias posiçôes dos anos de 1920, no que diz respeito à ideologia pequeno-burguesa que contamina todas as classes e perpetua o fascismo. Independente do teor das soluçôes que Levi apontará, 
voltadas para a revoluçáo camponesa e para a reforma radical do Estado, não se podem negar a clareza do pensamento nessa altura e a contribuição das imagens representadas ao longo do livro para a nossa compreensão.

4.

O romance de Vasco Pratolini trata o passado através da recriação ficcional de um pequeno mundo florentino, uma rua e seus arredores durante os anos de 1920 (mais precisamente, o biênio 1925-1926). Via del Corno, localizada atrás do Palazzo Vecchio, entre Borgo dei Greci e Via Vinegia, entre Piazza della Signoria e Santa Croce, transforma-se em personagem das histórias que se entrelaçam. Ainda que o romance retrate episódios que diretamente dizem respeito à afirmação do fascismo como regime (como a atuação dos esquadrões de perseguição, captura e extermínio), as histórias de seus personagens são levadas para o palco teatral para que se entre em cena a vida particular, a intimidade, a miudeza de seus moradores. Tais propostas narrativas são enfeixadas por um modo de transcrição capaz de estabelecer relaçóes com a história, pela origem do gênero e pela filiação com as crônicas florentinas antigas e medievais. A crônica daqueles pobres amantes e trabalhadores torna-se pública, assume a intenção de tornar a micro-história parte significativa do que poderia ser relato histórico.

Pratolini tinha muita intimidade com Florença e com as ruas estreitas próximas à Piazza della Signoria. Ali o escritor nasceu em 1913, de uma família operária. Interrompeu os estudos para assumir diversas ocupaçôes (foi tipógrafo, vendedor ambulante, garçom) e seguir uma carreira autodidata no mundo literário, no qual conheceu Elio Vittorini e publicou seus primeiros textos, em 1937. Colaborou em várias publicaçóes, algumas clandestinas durante o fascismo, participou ativamente da Resistência em Roma e após a guerra se transferiu para Nápoles, onde escreveu Cronache de poveri amanti. Escreveu também roteiros e argumentos para o cinema, colaborando com Luchino Visconti, Roberto Rossellini, Mario Bolognini, Franco Zeffirelli, Valerio Zurlini, Nanni Loy. Após os anos 1960 não escreveu mais em prosa.

Considerando a atitude intelectual que traz à luz uma criaçáo artística pensada para articular passado e presente no momento que define a derrocada do conflito mundial, quando Pratolini escreve Cronache di poveri amanti (História de pobres amantes) de um só fôlego, distante da Florença de sua infância e adolescência, ele procura se distanciar dos tempos da Resistência e superar as tensôes políticas e afetivas do imediato pós-guerra com uma instigante operação de imersão e distanciamento épico que recria quase à maneira de Brecht o ambiente táo conhecido dele. ${ }^{31}$ É o próprio escritor a declarar a filiaçáo de seu livro com a memória:

\footnotetext{
${ }^{31}$ JACOBBI, Ruggero. Introduzione a PRATOLINI, Vasco. Cronache di poveri amanti. Milano: Mondadori, 1974, p. x.
} 
“O ETERnO FASCISMO ITALIANO” E A RESISTÊNCIA DOS ROMANCES DE IGNAZIO Silone, Carlo Levi e Vasco Pratolini

Gabriela Kvacek Betella

Devia ser o meu primeiro livro, em vez disso foi o sexto, consegui escrevê-lo somente em 1946, de um só fôlego, como se corresse atrás dos fatos que já pareciam se dispor sozinhos sobre as páginas após eu os ter alimentado de memória e de fantasia por vinte anos. Pois eu morei em Via del Corno, e o rapaz que aparece no último capítulo do livro, e que se chama Renzo, sou eu. Morei ali de 1927 a 1930, num período muito importante, duro e doloroso para a minha vida. Imagine por exemplo levantar-se pela manhã às seis, no inverno, com o cansaço do dia anterior ainda consigo e o rosto se congela no sono por causa do frio que fazia dentro do quarto; mas foram também os anos nos quais primeira vez comecei a receber um salário e depois a dispor de duas ou três liras no domingo. Um daqueles momentos que resistem longamente na memória e relembrando deles dizemos: ah, se soubesse escrever teria algo sobre o que contar... ${ }^{32}$

Pratolini recria vielas e ruas de Florença com a ajuda da memória de infância, época em que residiu em Via del Corno, cenário principal da trama que se constitui, no entanto, de personagens fortemente simbólicos, criados para expor um passado em que os moradores de uma rua constituíam uma população reprimida pelas forças do poder. Os personagens e eventos são compostos de acordo com sua preponderância numa realidade psicológica que reconstitui o passado com base numa experiência do presente, assim como acontece conosco nos processos regulares da memória ao buscarmos estímulos para a compreensão maior do passado e do presente.

As personagens de Cronache di poveri amanti formam, naquele momento de début do fascismo que constitui o tempo da trama, um universo humano sufocado por vários agentes: o espaço físico e social, a repressão ideológica e psíquica, a submissão imposta pela influência ou pela força. Vale a pena explorar o tom coral que afirma o caráter coletivo sobre o impacto da modernidade nos ideais, amores, amizades e rebelióes. O romance marca a obra de Pratolini por ser uma das obras mais representativas do neorrealismo literário, mas especialmente porque o livro, planejado durante a última década da guerra, é escrito e publicado sob o impacto da reconstrução e das decisóes eleitorais que, em junho de 1946, instauram a República (parlamentar e pluripartidarista). As Cronache trazem memória coletiva nas histórias interconectadas, o que, para reforçar os preceitos de Walter Benjamin, assinala o caráter de história cujas vozes são, de certo modo, redimidas. A crônica de Via del Corno

\footnotetext{
${ }^{32}$ Doveva essere il mio primo libro, fu invece il sesto, riuscii a scriverlo solo nel ' 46 , tutto d'un fiato, come ricorrendo i fatti che ormai sembrava si disponessero da soli sulle pagine dopo che per vent'anni li avevo nutriti di memoria e di fantasia. Poiché io ho abitato in via del Corno, e il ragazzo che compare nell'ultimo capitolo del libro, e che si chiama Renzo, sono io. Vi ho abitato dal '27 al '30, in un periodo molto importante, duro e doloroso per la mia vita. Cos'era a esempio alzarsi al mattino alle sei, d'inverno, con ancora adosso la stanchezza del giorno avanti e la faccia gelatasi nel sonno per il freddo che faceva dentro la camera; ma furono anche gli anni in cui per la prima volta cominciai a percepire un salario e poi a disporre di due tre lire la domenica. Uno di quei momenti che resistono a lungo nella memoria e ripensando ai quali si dice: ah, se sapessi scrivere ne avrei di che raccontare... Apud VILLA, Carlo. Invito alla lettura di Vasco Pratolini. 3. ed. Milano: Mursia, 1977 , p. 60, tradução nossa.
} 
“O ETERnO FASCISMO ITALIANO” E A RESISTÊNCIA DOS ROMANCES DE IGNAZIO Silone, Carlo Levi e Vasco Pratolini

Gabriela Kvacek Betella

passa inevitavelmente pelo dia após dia de seus moradores, expressa no romance através da coralidade que estabelece uma dimensão igualitária entre as personagens na narrativa e nas cenas. Nesse sentido, a abertura do romance é exemplar:

Cantou o galo do carvoeiro Nesi, apagou-se a lanterna do Albergo Cervia. A passagem do bonde que reconduz os motorneiros da turma da noite fez estremecer Oreste, o barbeiro, que dorme na loja de Via dei Leoni, a cinquenta metros de Via del Corno. Amanhã, dia de feira, seu primeiro freguês será o feitor de Calenzano que aparece toda sexta-feira com a barba de uma semana. Na Torre di Arnolfo o marzocco voltado para o oriente, garante bom tempo. $\mathrm{Na}$ viela atrás de Palazzo Vecchio os gatos desfazem os embrulhos de lixo. As casas são tão juntas umas das outras que o luar apenas banha as janelas dos últimos andares. Mas o galo de Nesi, no terraço, viu a lua e cantou.

Depois de apagada a luz do hotel, só uma janela permanece iluminada em Via del Corno, a do quarto da Senhora, que passa a noite em companhia das feridas de sua garganta. O cavalo de Corrado, o ferreiro, bate de vez em quando com as patas: sua manjedoura fica atrás da forja. É o mês de maio, e dentro da noite, sem a menor aragem, surgem os maus cheiros. Diante da oficina do ferreiro acumula-se o esterco dos cavalos ferrados durante o dia. O pequeno mictório, na esquina de Via dei Leoni, está completamente cheio e já transborda há meses. Os embrulhos e montes de lixo foram jogados pelas portas das casas, como de costume. ${ }^{33}$

O romance traz estampados na primeira página os ritmos, os odores, os personagens, suas ocupaçóes e hábitos, numa cadência orquestrada pela força dos verbos no presente. Comparecem os espaços cruciais da ação na pequena rua e nos arredores. O narrador parece conduzir uma câmera imaginária que capta os detalhes e recorda a noite que cai sobre os moradores de Via del Corno, trazendo uma bela amostra do cotidiano através dos seus resquícios e resíduos. A intensidade das imagens (cuja condução é cinematográfica) se multi-

\footnotetext{
${ }_{33}$ PRATOLINI, Vasco. História de pobres amantes. Trad. Carla Inama de Queirós. Rio de Janeiro: Civilização Brasileira, 1963, p. 5.

Ha cantato il grillo del Nesi carbonaio, si è spenta la lanterna dell'Albergo Cervia. Il passaggio della vettura che riconduce i tranvieri del turno di notte ha fatto sussultare Oreste parrucchiere che dorme nella bottega di via dei Leoni, cinquanta metri da via del Corno. Domani, giorno di mercato, il suo primo cliente sarà il fattore di Calenzano che ogni venerdí mattina si presenta con la barba di una settimana. Sulla torre di Arnolfo il marzocco rivolto verso oriente garantisce il bel tempo. Nel vicolo dietro Palazzo Vecchio i gatti disfanno i fagotti dell'immondizia. Le case sono cosí a ridosso che la luce lunare sfiora appena le finestre degli ultimi piani. Ma il gallo del Nesi, ch'è in terrazza, l'ha vista ed ha cantato.

Spenta la lanterna elettrica dell'Albergo, in via del Corno resta accesa una sola finestra, nella camera della Signora che trascorre la notte in compagnia delle sue piaghe alla gola. Il cavallo di Corrado maniscalco scalpita di tanto in tanto: ha la mangiatoia sistemata nel retro della forgia. È maggio, e nell'aria noturna, senza alito di vento, affiorano i cattivi odori. Davanti alla mascalcia è accumulato lo sterco dei cavalli ferrati durante la giornata. Il monumentino, all'angolo di via dei Leoni, è colmo e staripa ormai da mesi. I fagotti e le biche della spazzatura domestica sono stati seminati fuori delle porte come di consueto. PRATOLINI, Vasco. Cronache di poveri amanti. Milano: Mondadori, 1974, p. 7.
} 
“O ETERnO FASCISMO ITALIANO” E A RESISTÊNCIA DOS ROMANCES DE IGNAZIO Silone,

plica quando nos lembramos do fato de que o autor compóe o texto distante desse local real. Pratolini convoca até os restos para apresentar a rua e tornar mais vivas as lembranças do passado no presente, ainda que seja pelo registro dos maus cheiros aos quais todos já tinham se acostumado.

Ainda que as histórias vividas pelas personagens de Cronache apresentem gradaçóes do bem e do mal, o romance é maniqueísta como a narrativa popular, como alguns exemplos da narrativa oral, de modo a oferecer exemplaridade, como se àquela altura o fascismo devesse aparecer através das atitudes mais funestas e bem próximas a nossa vida cotidiana. Marca presença o avarento Nesi carbonaio, cujo percurso atravessa a linha que separa a condiçáo de explorador para explorado e humilhado, graças à intervenção da Signora, enigmática e reservada personagem que encarna o poder e o controle sobre as vidas em Via del Corno, exercendo sua autoridade pela influência pessoal e especialmente pela capacidade de monitoramento da rua, graças às janelas do tipo persiana sempre escoltadas por uma das informantes abrigadas pela Signora.

Além dessas trajetórias que se cruzam, o universo de personagens conta com os angeli custodi (os "anjos da guarda") - Aurora, Milena, Bianca e Clara, moças criadas na rua e queridas, porém com destinos bastante diferentes, com histórias de amor cheias de contratempos. Sáo elas e seus pares os poveri amanti centrais da narrativa, suas alegrias e amarguras concentram a essência da vida difícil naqueles anos de 1920 e a continuidade do aprendizado sobre as necessidades comuns, marcado pelo ritmo cotidiano ameaçado pelas diferentes forças de repressão instauradas sobre aqueles jovens.

Uma das linhas narrativas, melhor dizendo, um dos eventos que pode ser visto como desencadeador da maioria das relaçôes entre as personagens é o roubo acontecido na Via Bolognese. $\mathrm{O}$ romance começa com o fato acontecido e a partir dele a ação mapeia as relaçôes de poder, e interesses na rua, assim como também revela a sombra fascista sobre as reaçôes. Quando a Signora ameaça Nesi, que havia sido receptador do roubo, ele tenta colocar o fascista Carlino contra ela. Benemérita do Fascio, a Signora é intocável, e seus planos se concluem da melhor maneira para ela, inclusive com Nesi sofrendo um colapso. O comentário do brigadiere é certeiro: "Mais uma vez a Velha se saiu bem! Até a Morte está do seu lado!". ${ }^{34}$ Vale lembrar que assim como a janela da Signora permanece iluminada conforme a descrição na abertura do romance, o desfecho do episódio também a deixa soberana, com a presença que não se extingue, como o mal que subsiste mesmo sob uma forma imperfeita.

Algumas das histórias (como a de Nesi carbonaio) se definem na primeira metade do romance. Na segunda metade, diminuído o foco, a ação se concentra sobre os fascistas, especialmente Osvaldo Liverani, e os comunistas Corrado maniscalco (o Maciste) e Ugo. O ponto alto do confronto entre as forças repressoras e os heróis do povo é a Notte dell'Apocalisse, na

\footnotetext{
${ }^{34}$ PRATOLINI, Vasco. História de pobres amantes, op. cit., 1963, p. 105.

La Vecchia l'ha fatta pulita un'altra volta! Anche la Morte le tiene di mano! PRATOLINI, Vasco, op. cit., 1974.
} 
qual os fascistas eliminam o gigante Maciste e afugentam seu aprendiz. Não obstante as definiçóes maniqueístas, o romance institui simbologias poderosas para desenhar o retrato de uma época, como se o autor insistisse em representar as forças envolvidas nos destinos das pessoas para preservar, no momento de desafogo em que a escrita acontece, os ideais de liberdade, recordando os tempos repressores e seus agentes personificados entre os homens comuns.

5.

Para fomentar a continuidade do debate, resta-nos lançar mão de uma constatação imperiosa: Fontamara prova sua fidelidade com a representação da realidade italiana quando estabelece afinidades com um romance como Conversazione in Sicilia (1941, publicado no final dos anos de 1930 na revista Letteratura), de Elio Vittorini. Antes de filiar o primeiro romance de Silone ao elenco de peripécias narrativas contemporâneas, deve-se sobretudo pensar na relação que Fontamara estabelece com seus predecessores e com os autores que pertenceram às geraçōes intelectuais próximas do autor abruzzese. A partir daí, é possível discutir o papel desses escritores e das obras num contexto maior de regionalismos ou, melhor dizendo, de literatura de resistência, para utilizar a expressão de Italo Calvino.

As diferenças entre os procedimentos refletem-se no tom dos testemunhos e estabelecem a distinção de origem. Se Carlo Levi prioriza o relato recortado da memória para reviver em tempos limítrofes as lembranças do exílio, seu texto deve muito à posição intelectual ocupada pelo político que pôde revisar certos conceitos (como o de ideologia pequeno-burguesa) e vislumbrar uma espécie de legado do período fascista, reduzindo as perspectivas de anulação das tiranias. Poucos anos depois da narrativa de Levi ser composta, no momento de abertura democrática, Vasco Pratolini legitima suas origens proletárias e sua formação autodidata no romance que vislumbra um horizonte de expectativas um pouco mais amplo, dado o pacto que o texto estabelece com os símbolos que cria e vira pelo avesso, relativizando seus conteúdos.

Podemos examinar momentos históricos diferentes: o tempo da trama (os anos entre 1920 e 1930 com Silone, os anos de 1930, no caso do testemunho de Levi, e a década de 1920, com Pratolini), o tempo da criação (1930 em Fontamara, 1943 e 1944 em Cristo si è fermato a Eboli e 1946 para as Cronache di poveri amanti) e a extensão das reavaliaçóes do neorrealismo literário italiano, que perduram até hoje. As condiçóes (dramáticas ou náo) sob as quais a leitura de um tempo que pede reflexão é realizada também podem ser examinadas e devem partir do fato de que a obra retrata uma visão particular de um contexto. A interpretação é valorizada na medida em que se considerem as nuances dessa impressão, seja através da criação ficcional ou dos aspectos de testemunho, nas três narrativas. É como se 
pudéssemos mapear ficção e memória para enxergar uma amplitude maior de experiências reconstituídas, de empenho ideológico, de frustração.

O testemunho dos autores pode ser compreendido no sentido de sobrevivência a eventos-limite localizados nos dois decênios que antecederam ao mais radical dos eventos, a experiência da guerra. Além disso, os textos estabelecem um elo entre passado vivido e presente da composição, que exerce influência sobre a fatura do texto e norteia o projeto literário dos escritores. Se determinadas experiências são retomadas numa época diferente, esta contribui para a reconstruçáo da verdade, que aflora graças ao equilíbrio entre a memória pessoal (subjetiva) e o real, a construção de uma identidade.

As narrativas lidam com a memória individual, com a memória coletiva e com a história, valorizando-as e livrando-as das banalizaçôes. As tramas são construídas com base no diálogo entre os eventos marcantes e o cotidiano, com uma base ficcional - muito menor, no caso de Cristo si è fermato a Eboli - disposta a não deixar o passado (ou o presente) se dissolver em meio à avalanche memorialista, ao apelo subjetivo, à falta de referencialidade. Os autores questionam os limites da representação com a escrita, ampliando as possibilidades do registro de memória. Em primeiro lugar, os fatos que pedem testemunho sáo de fato registrados, porém integrando uma reelaboração artística, ultrapassando o caráter de denúncia ou de reportagem. As narrativas estabelecem uma ética de representação disposta a colocar em xeque o real, ou seja, o passado ou o presente, cujo retrato não pode encobrir de modo algum as injustiças. Portanto, Silone, Levi e Pratolini sáo capazes de elaborar narrativas cuja principal intenção é restabelecer uma continuidade histórica, ainda que seja através da manipulação do real que, por sua vez, estabelece uma ruptura. Por mais que sejamos levados a pensar em novas possibilidades narrativas, o resultado que observamos é a afirmação da resistência do caráter literário.

\section{Referências bibliográficas}

BEN-GHIAT, Ruth. Fascism, Writing, and Memory: The Realist Aesthetic in Italy, 19301950. The Journal of Modern History, v. 67, n. 3, p. 627-665, Sep. 1995.

BENJAMIN, Walter. Sobre o conceito de história. In: BENJAMIN, Walter. Magia e técnica, arte e política. Ensaios sobre literatura e história da cultura. Trad. Sergio Paulo Rouanet. 3. ed. São Paulo: Brasiliense, 1987, p. 222-232.

CANDIDO, Antonio. Literatura e subdesenvolvimento. In: CANDIDO, Antonio. $A$ Educação pela Noite e outros ensaios. 2. ed. São Paulo: Ática, 1989, p. 140-162.

FABRIS, Mariarosaria. A questáo neo-realista e sua recepção no Brasil. In: FABRIS, Mariarosaria. Nelson Pereira dos Santos: um olhar neo-realista? São Paulo: Edusp, 1994. . O neo-realismo cinematográfico italiano: uma leitura. São Paulo: Edusp, 1996. 
“O ETERno Fascismo italiano” E A RESistênCia dos Romances de Ignazio Silone,

GENTILE, Emilio. Fascismo: Storia e interpretazione. Roma-Bari: Laterza, 2002.

(Org.). Modernità totalitaria: Il fascismo italiano. Roma-Bari: Laterza, 2008.

JACOBBI, Ruggero. Introduzione a PRATOLINI, Vasco. Cronache di poveri amanti. Milano: Mondadori, 1974.

LEVI, Carlo. Cristo parou em Eboli. Trad. Wilma F. Ronald de Carvalho. Rio de Janeiro: Nova Fronteira, 1986.

. Cristo si è fermato a Eboli. 17. ed. Torino: Einaudi, 2003.

MARCUS, Millicent. Italian Film in the Light of Neorealism. New Jersey: Princeton, 1986.

MICCICHÉ, Lino. Cristo si è fermato a Eboli. In: MICCICHÉ, Lino. Cinema italiano degli anni '70. Cronache 1969-1979. 2. ed. Venezia: Marsilio, 1989, p. 318-321.

PETERLE, Patricia. Ignazio Silone: encruzilhadas entre literatura, história e política. Niterói: Comunità, 2011.

PRATOLINI, Vasco. Cronache di poveri amanti. Milano: Mondadori, 1974.

. História de pobres amantes. Trad. Carla Inama de Queirós. Rio de Janeiro: Civilização Brasileira, 1963.

ROSA, Alberto Asor. Scrittori e popolo. Il populismo nella letteratura italiana contemporanea. Torino: Einaudi, 1988 (primeira edição 1965).

SALVATORELLI, Luigi; MIRA, Giovanni. Storia d'Italia nel periodo fascista. 3. ed. Milano: Mondadori, 1970. 2 v.

SASSOON, Donald. Mussolini e a ascensão do fascismo. Trad. Clóvis Marques. Rio de Janeiro: Agir, 2009.

SILONE, Ignazio. Fontamara. Int. Aurelio Picca. Roma: Newton Compton, 2010. . Fontamara. Trad. Doris Cavallari. São Paulo: Berlendis \& Vertecchia, 2003.

VILLA, Carlo. Invito alla lettura di Vasco Pratolini. 3. ed. Milano: Mursia, 1977. 